QIJIS: Qudus International Journal of Islamic Studies

Volume 6, Issue 1, February 2018

\title{
THE DAWN SKY BRIGHTNESS OBSERVATIONS IN THE PRELIMINARY SHUBUH PRAYER TIME DETERMINATION
}

\author{
Laksmiyanti Annake Harijadi Noor \\ Bandung Institute of Technology (ITB) Bandung, West Java \\ anna.aihaibara@gmail.com \\ Fahmi Fatwa Rosyadi Satria Hamdani \\ Bandung Islamic University (UNISBA) Bandung, West Java \\ fatwa19@gmail.co.id
}

\begin{abstract}
The indication of began to enter the shubuh prayer time is when emerge the morning dawn and lasted until the sun rises. The sun position when emerge the morning dawn is below the intrinsic horizon marked with a minus sign (-) with the value of a certain height. The Ministry of Religious Affairs has set the sun altitudes of dawn in the shubuh prayer time with minus (-) $19^{\circ}+$ sunrise/sunset altitudes as standard is the reference time of dawn prayers in Indonesia. However, this provision in fact reap discourse in some quarters because it is not in accordance with the phenomenon of morning dawn emergence at the beginning of the shubuh prayer time empirically. This study aims to decide the morning dawn, as the beginning of dawn determinant. The tool used in this study is the Sky Quality Meter (SQM), to detecting the morning dawn emergence as a sign of the beginning of the shubuh prayer time. The results of this study found that the brightness of the sky throughout
\end{abstract}


the night or the morning dawn in Tayu Beach, Pati, Central Java, in the span of four days of observation that is at 04.31 A.M. with an average altitude of the sun is $-17^{\circ}\left(17^{\circ}\right.$ below the horizon).

Keyword: Morning Dawn, Shubuh Prayer, SQM, Sun Altitudes.

\section{A. Introduction}

The start time of prayer is one of the studies discussed in the learning of Ilmu Falak. As studies in languages other Ilmu Falak, the initial determination prayers can note their timing. This is because prayer is one of the worship time is determined by the movement of the sun. Starting from the time of Maghrib prayers are mandatory, such as Isha, Dawn, Noon, and Asr, up to the sunnah prayers as Duha prayer, or eclipse prayer (Hamdani, 2016: 55-69). Determining the beginning of each hour of prayer at this time can be known by a variety of methods of application, such as by using a shadow Sun, Sky Quality Meter (SQM), theodolite, and others. In this regard, Allah has said in Q.S. an-Nisa' [4]: 103:

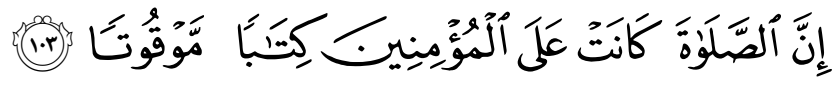

"Indeed, prayer is a obligatory timed over those who believe." (Q.S. an-Nisa' [4]: 103:)

Beginning of the entry time to undergo the shubuh prayer worship, marked by the dawn of the sadik, that white light and uniformly extends horizontally in the Eastern horizon due to scattering of sunlight is about the atmosphere (Rohmah, 2012: 1). Indications began to enter the shubuh prayer time is when the morning dawn emerged, and lasted until sunrise. The sun position at dawn appearance of the sadik is below the horizon essentials (marked with a minus sign) to the value of a certain height. The Ministry of Religious Affairs has set the altitude of the sun when the shubuh prayer is $-19^{\circ}+$ sunrise/sunset altitudes as standard is the reference time of the shubuh prayer in Indonesia and it has 
been considered appropriate to review the proposition of syar' $i$ and astronomical (Kementerian Agama RI, 2013: 83).

Problems concerning the determination of the start time of the Shubuh prayer tapered in 2009 through Qiblati magazine in Indonesia are concerned about the early time of the shubuh prayer and even three editions (Qiblati magazine Edisi 8, Volume 4: "Salah Kaprah Waktu Shubuh: Fajar Kazib dan Fajar Shadiq", Edisi 9, Volume 4: "Salah Kaprah Waktu Shubuh: Memajukan Waktu Shubuh adalah Bid'ah Kuno", Edisi 10, Volume 4: "Salah Kaprah Waktu Shubuh: Kesaksian dan Fatwa Para Ulama”). They conduct repeated research on the meaning of the dawn in Q.S. al-Baqarah [2]: 187 and some of the traditions of the Prophet that turned out to be based on the observation of which they did in some places in East Java, Central Java, and Yogyakarta are incompatible with the phenomenon sadik dawn today. According to the magazine team Qiblati the beginning of the shubuh prayer time in Indonesia too soon about 24 minutes (Dewan Hisbah Persis, 2016: 26).

In order to verify the initial determination of the Shubuh prayer time in Indonesia, then a lot of research conducted by experts astronomy and astronomy studies the sky brightness. The most conventional way are many and are commonly used to measure the brightness of the sky is using photometry (Rohmah, 2012: 5). However photometry takes a long time and the equiament is not cheap. Currently, besides using a photometric method, there is a tool called Sky Quality Meter (SQM). SQM produces research using data such as sky brightness throughout the night somewhere and practically can be used to detect the emergence of dawn sadik as a sign of the beginning of the shubuh prayer time. The results of SQM measurements defined in the magnitude brightness of the sky that is magnitudes per square arcsecond unit (MPDB) so that making it easier to study (Al Faruq, 2013: 4). 


\section{B. Discussion}

\section{Theoretical Basis}

In language, dawn or in Mu'jam al-Ma'ani al-Fajr alJami' i.e.:

$$
\text { انكشافُ ظلمِة الليل عن نور الصّبح }
$$

"Lighting the dark night of the morning light" (Mu'jam al-Ma'ani al-Fajr al-Jami', n.y.: 1).

Lighting the morning light is not the sun, but the white light rather light that appears on the eastern horizon shortly before sunrise (Hambali, 2011: 124).

Still in the dictionary described:

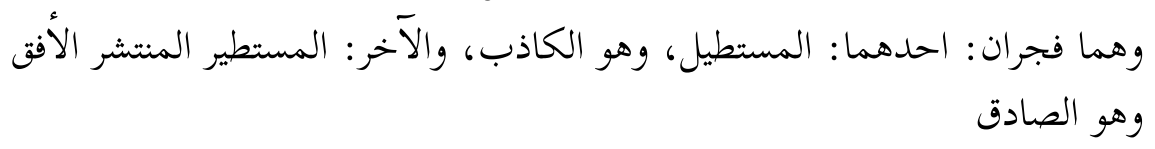

"There are two kinds of dawn, the first extending (vertically) called kazib, and more uniform and widespread in the horizon (horizontally) called sadik" (Mu'jam al-Ma'ani al-Fajr al-Jami', n.y.: 1).

In accordance with the agreement of the scholars that there are two kinds of dawn, the dawn of the dawn kazib and sadik. Dawn kazib a rather bright light that appeared looming and pointing to the heavens like wolves during the early hours of the morning. According to an-Nawawi (d. 676 H/1277 M), called the dawn kazib (Dawn lie) since the dawn of this at first appeared but then disappeared and the sky went dark back (an-Nawawi, al-Majmu' Syarh al-Muhadzdzab: Volume 3; Mawaqit ash-Shalah: 48). Therefore Shari'ah does not make kazib dawn as the basis of worship.

Dawn kazib appear first before dawn sadik vertically on the eastern horizon is an astronomical phenomenon called the zodiacal light (light zodiac), the reflection and scattering of sunlight by interplanetary dust. Thomas Jamaladin in his "Waktu Shubuh Ditinjau Secara Astronomi dan Syar'i" states that: 
"Dawn kazib did not dawn in the common understanding, which is called the astronomical zodiac light. Zodiac light caused by the scattering of sunlight by interplanetary dust scattered in the ecliptic plane in the sky through a series of the zodiac (a series of constellations that seem impassable sun). Therefore kazib dawn seemed stuck up like wolves, the direction corresponding to the direction of the ecliptic. Dawn kazib appear sadik before dawn when the night was still dark" (Djamaluddin, 2010a).

While the dawn of the sadik is an emerging dawn after dawn kazib. According Wahbah az-Zuhaili, the dawn of the sadik is a white light visible on the eastern horizon and spread (horizontally) that appears shortly after dawn or before sunrise kazib (az-Zuhaili, n.y.: 555).

Based on the arguments of the Qur'an and the Hadith, the scholars have agreed that the dawn of the sadik is a dawn that bodes influx of dawn. Named sadik dawn because dawn is the dawn of the 'right' or the true dawn. Starting from the emergence of white light that spreads along the eastern horizon then gradually becoming brightening sky.

Thomas Jamaluddin in his writings "Waktu Shubuh Ditinjau Secara Astronomi dan Syar'i" also mentioned the dawn sadik:

"Dawn sadik is the scattering of sunlight by particles in the air surrounding the earth (the atmosphere). In the language of the Koran that phenomenon likened to the phrase 'the white thread from a black thread', ie the transition from the dark night (black) towards the emergence of light (white). In the language of physics of black means no light is emitted, and no white light emitted meaningful. Because the light source of the sun and penghamburnya is air, then crosswise dawn light along the horizon (the horizon, the skyline). It was a sign of the end of the night, before sunrise. The more the sun approached the horizon, the bright dawn of the sadik. Thus, the limit that can be used is the distance of the sun below the horizon" (Djamaluddin, 2010a).

The start time of prayer is based on the phenomenon of the sun, the daily movement of the sun due to the earth's rotation. Position or the position of the sun during its movement from sunrise to sunset since become a major factor causing the difference in time and space on earth that cause different the time of prayer anyway. The sun's position, including altitude or distance 
zenith, is the most important astronomical data connection with the emergence of dawn sadik, especially as the entry at dawn (Djamaluddin, 2010b).

The astronomical, based on the position of the sun at dawn, there are three types of light dawn (morning twilight), namely:

a. Dawn astronomy/falaky (dawn astronomical twilight) is when the sun is at a position of $18^{\circ}$ to $12^{\circ}$ below the horizon. The dawn light as a sign of the end of the night because of the star's light began to fade due to scattering of sunlight that began to emerge;

b. Dawn cruise/bahry (nautical twilight) is when the sun is at position $12^{\circ}$ to $6^{\circ}$ below the horizon. The morning light revealed the horizon or skyline that appears even more clearly when at sea;

c. Dawn civil/madany (civil twilight) is when the sun is at $6^{\circ}$ to $0^{\circ}$ below the horizon. At this time, the objects in the open already visible even without lights (Anugraha, 2012: 90).

Early dawn marked the emergence of white light that spread in the east along with the start dimming of starlight due to the influence of sunlight that began to emerge. So astronomically, the emergence of dawn sadik can be understood as the dawn of astronomy (dawn astronomical twilight) take place when the sky is no longer the dark when the sun is at position $18^{\circ}$ below the horizon $\left(-18^{\circ}\right)$ or at the zenith distance $\mathrm{z}=108^{\circ}$ (Anugraha, 2012: 90).

\section{Instrument}

SQM used in research examining the emergence of dawn sadik as an early indication of the shubuh prayer time is SQM LUDL models (Lens USB-Data Logger). LU-DL SQM SQM is a model that has a lens with a USB connection and also have the capability of data logger which can automatically record data with the battery adapter without a computer connection for observation. SQM LU-DL measuring the apparent brightness of the night sky 
with the results of readings in the magnitude magnitudes per square arcsecond unit (MPDB) via a USB connection with or without a computer and capable of reading data contained in the internal recording (SQM-LU-DL Operator's Manual, 2016).

SQM LU-DL has a FLASH Memory component as data storage and Real Time Clock observations as accurate time on the device SQM LU-DL. During the observation, the light sensor will capture and record the condition of the observation area and processed in a micro-controller.

When analysts want to read the observed data, SQM LUDL connected to the computer via USB cable. Commands sent from the computer will be forwarded to the micro-controller will respond to commands by sending data to a computer. Observation data from SQM LU-DL can be read using software Unihedron Device Manager.

\section{Observation}

Stages of data acquisition in SQM as follows:

a. Install SQM is flat on a tripod that has been equipped with a bow to read the scales tilt angle to be used;

b. Navigate SQM facing the eastern horizon, determining true east can use Stellarium application (or a similar application) to facilitate or you can also use a compass;

c. Adjust the tilt angle of the installation of SQM. SQM is installed with a slope angle of $30^{\circ}$ or zenith distance of $60^{\circ}$, so that the area can be structured appearance sadik dawn in the eastern horizon;

d. Insert the battery adapter in SQM and SQM also automatically record data with the time interval every 10 seconds during the data collection is done in the time span from 02.00 A.M. until 06.00 A.M.;

e. Until the predetermined time, remove the battery adapter from SQM and the data recording was completed.

Observations dawn sadik use SQM requires observation locations in place that allows getting loose eastern horizon with 
no obstacles and the dark areas are free from light pollution. Therefore, the researcher took observation locations in Tayu Beach in Pati, Central Java. Tayu beach located in the village Keboromo, District Tayu, Pati regency, Central Java, with coordinates $6^{\circ} 32$ '18.38 "S, $111^{\circ} 04^{\prime}$ ' 26.76" E and an elevation of 0 meters above sea level is a lowland area can easily get immediate the eastern horizon in the form of the high seas.

Tayu Beach, Pati is a dark area and minimal light pollution so the place is considered representative to be used as a test site using a sadik dawn SQM. These observations were performed for 7 days within the period from August to September 2016, held on 24, 25, 26, August 31 and from 1 to 3 September 2016. However, during the 7 days of observation, not all of which have clear skies, but only 4 days in a row on 31 August and 1 to 3 September 2016 when the sky is clear. During the 4 days of observation of the state of clear skies and produce a stable observation data so that it can be taken as the corresponding results for later analysis. Observations were made in the span at 02.00 A.M. until 06.00 A.M. each day with interval data retrieval per 10 seconds.

\section{Result}

The graph shows that within the period of observation taken at 03.00 A.M. until late at night after 04.12 A.M. that is stable at the night sky brightness value measured is 21 MPDB. Graph gradually ramps and declines signal a change in brightness of the sky because the smaller the value, the brighter the sky until morning when the sun rises at 05.34 A.M. on August 31, 2016 and September 1, 2016 at 05.33 A.M. on 2 and 3 September 2016. 


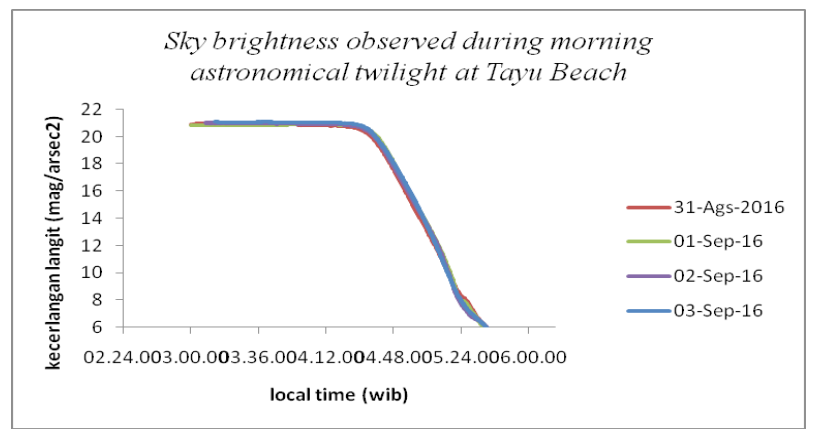

Picture 1 The sky brightness Dawn Over 4 Days Observations in Tayu Beach

Through the graph, it appears that the pattern of changes in sky brightness of the dark (stable graph) into light (graph ramps) as a harbinger of the end of the night is a reference to the appearance of dawn sadik (the graph area inside the circle). In determining the time of the emergence of dawn sadik, can be searched through the sky brightness value depending on the resulting data. So it can be analyzed that the beginning of the shubuh prayer time is when the value changes depending on the brightness of the sky is negative end of the graph is stable.

Graph data that was originally in the form of the local time modified in the form of standard time using the time before sunrise to sunrise time reference (take a small sample graph September 1, 2016).

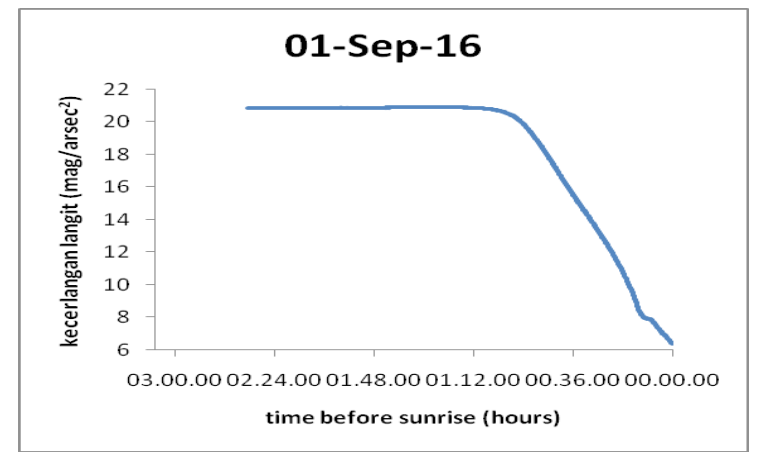

Picture 2 Dawn sky brightness on September 1, 2016 in Tayu Beach 
Graph ramps be an indication of the end of the evening at the same time the emergence of dawn sadik. Changes in the pattern on the graph that initially showed stable to declining value of sky brightness difference is negative. The processed data is the apparent brightness of the sky dawn on September 1, 2016 at Ms. Excel shows that the negative value of sky brightness difference -0.002 time 1 hour 0 minutes 51 seconds before sunrise. Sunrise time on September 1, 2016 is at 05.34 A.M., so it can be seen the emergence of the sadik or early dawn the shubuh prayer time 1 hour 0 minutes 51 seconds before sunrise is at 04.33 A.M. (Anugraha, 2012: 81).

In summary the results of observational data processed in Tayu Beach can be seen in the following table:

\begin{tabular}{ccccc}
\hline \multicolumn{1}{c}{ Date } & $\begin{array}{c}\text { Sunrise } \\
\text { Time }\end{array}$ & $\begin{array}{c}\text { Time Before } \\
\text { Sunrise }\end{array}$ & $\begin{array}{c}\text { Occurrences } \\
\text { Time } \\
\text { Morning } \\
\text { Dawn }\end{array}$ & $\begin{array}{c}\text { Sun } \\
\text { Altitudes }\end{array}$ \\
\hline Agustus 31, 2016 & 05.34 WIB & 1 h 5 m 14 s & $04.29 \mathrm{WIB}$ & $-18^{\circ}$ \\
\hline September 1, 2016 & 05.34 WIB & 1 h 0 m 51 s & $04.33 \mathrm{WIB}$ & $-16^{\circ}$ \\
\hline September 2, 2016 & 05.33 WIB & 1 h 1 m 21 s & $04.31 \mathrm{WIB}$ & $-17^{\circ}$ \\
\hline September 3, 2016 & 05.33 WIB & 1 h 1 m 21 s & $04.31 \mathrm{WIB}$ & $-17^{\circ}$ \\
\hline
\end{tabular}

Table 1 Summary of Observation Data Processed in Tayu Beach

From these data, it is known that the average time of appearance of dawn sadik in the span of four days of observation that is at 4:31 a.m with an average altitude of the sun is $-17^{\circ}\left(17^{\circ}\right.$ below the horizon). Early dawn of time based on the results of these observations is then matched with the emergence of the phenomenon of dawn sadik on Stellarium applications and proven to be appropriate.

\section{Conclusion}

The observed data over a period of months from August to September showed that the average time of appearance of dawn sadik i.e. at 04.31 A.M., with an average altitude of the sun is $-17^{\circ}\left(17^{\circ}\right.$ below the horizon $)$. This proves that the 
start time of the shubuh prayer by the method of reckoning Kementerian Agama RI faster compared with the beginning of the shubuh prayer time observations using the device SQM. The observation of the dawn sky brightness using SQM is considered accurate because it corresponds to the emergence of dawn sadik phenomenon empirically. 


\section{EFERENCES}

Al Faruq, Ahmad Ridwan. 2013. "Kecerlangan Langit Malam Arah Zenit di Observatorium Bosscha dan Analisis Awal Waktu Shubuh dan Isya Menggunakan Sky Quality Meter", Skripsi, Universitas Pendidikan Indonesia Bandung. al-Ma'ani al-Fajr al-Jami', www.almaany.com/dict/ar-ar/الفجر. an-Nawawi, Abu Zakariyya Yahya bin Syaraf. n.y. al-Majmu' Syarh al-Muhadzdzab. Jakarta: Pustaka Azzam.

Anugraha, Rinto. 2012. Mekanika Benda Langit (Diktat Jurusan Fisika Fakultas MIPA). Yogyakarta: Universitas Gadjah Mada.

Arumaningtyas, Eka Puspita, et al. 2012. "Morning Twilight Measured at Bandung and Jombang", International Conference on Physics and its Applications.

az-Zuhaili, Wahbah. 2011. Fiqh al-Islami wa Adillatuhu. Jakarta: Gema Insani Press.

Cinzano, P. 2005. "Night Sky Photometry with Sky Quality Meter", ISTIL International Report, 1.4, www.unihedron.com/ project/darksky.

Dewan Hisbah Persis, "10 Keputusan Dewan Hisbah Persis: (8) Awal Waktu Shubuh", Risalah, Number 1, Year 54, Jumadil Tsani 1437/April 2016.

Djamaluddin, Thomas. 2010a. "Waktu Shubuh Ditinjau Secara Astronomi dan Syar'i”, https://tdjamaluddin.wordpress. com /2010/04/15/waktu-shubuh-ditinjau-secaraastronomi-dan-syari/, accessed June 13, 2016.

. 2010b. "Matahari dan Penentuan Jadwal Shalat", https:// tdjamaluddin.wordpress.com/2010/04/19/mataharidan-penentuan-jadwal-shalat/, accessed June 13, 2016. 
Hambali, Slamet. 2011. Ilmu Falak 1 Penentuan Awal Waktu Shalat dan Arah Kiblat Seluruh Dunia. Semarang: Program Pascasarjana IAIN Walisongo.

Hamdani, Fahmi Fatwa Rosyadi Satria. "Penerapan Model Contextual Teaching and Learning (CTL) dalam Pembelajaran Ilmu Falak", Jurnal al-Murabbi, Volume 3, Number 1, July 2016, STIT Islamiyah Ngawi.

Herdiwijaya, Dhani. 20-21 Agustus 2016. "Waktu Shubuh: Tinjauan Pengamatan Astronomi", Halaqah Nasional Ahli Hisab dan Fikih "Kajian Ulang atas Waktu Shubuh dan Tindak Lanjut Konsep Kalender Islam Global Tunggal”, Majelis Tarjih dan Tajdid Pimpinan Pusat Muhammadiyah, Yogyakarta.

Kementerian Agama RI. 2013. Buku Saku Hisab Rukyat. Jakarta: Sub-Direktorat Pembinaan Syariah dan Hisab Rukyat Direktorat Urusan Agama Islam dan Pembinaan Syariah Direktorat Jenderal Bimbingan Masyarakat Islam.

Rohmah, Nihayatur. 2012. Syafaq dan Fajar, Verifikasi dengan Aplikasi Fotometri: Tinjauan Syar'i dan Astronomi. Yogyakarta: Lintang Rasi Aksara Books.

SQM-LU-DL Operator's Manual, 2016, http://www.unihedron. com/projects/sqm-lu-dl/. 
